\title{
Positive suggestion techniques in somatic medicine: A review of the empirical studies
}

\author{
ZOLTÁN KEKECS*, KATALIN VARGA
}

\author{
Department of Affective Psychology, Institute of Psychology, Eötvös Loránd University, Budapest, Hungary \\ *Corresponding author: Zoltán Kekecs; Department of Affective Psychology, Institute of Psychology, Eötvös Loránd University; \\ Izabella u. 46, H-1064 Budapest, Hungary; Phone: +36-30-554-58-73; Fax: +36-1-461-2691; E-mail: kekecs.zoltan@gmail.com
}

(Received: March 28, 2013; Revised manuscript received: July 7, 2013; Accepted: July 24, 2013)

\begin{abstract}
Introduction: There is an ever reoccurring question in medical practice: Does the positive attitude and communication of the medical staff make any difference? Aim: Our aim is to present a comprehensive overview of the medically relevant effects of positive suggestions by reviewing the recent literature. Methods: We will review the studies measuring the effects of suggestive communication of the past 20 years. In cases of studies presented in more details we quote from the suggestion scripts used in the study, too. Results: Some of the reviewed papers report that positive suggestions lead to decreased pain and use of pain medication and positively affect physiological factors like bowel motility, blood pressure and bleeding during surgery as well. However, the literature also contains studies in which only partial or no positive effects were found. Conclusions: We emphasize further, more detailed investigation of positive suggestion techniques and its integration into the education of medical professionals.
\end{abstract}

Keywords: positive communication, positive suggestions, therapeutic suggestions, hypnosis, medical communication, controlled clinical studies

\section{Introduction}

This paper is an updated version of a previous one published in Hungarian in Orvosi Hetilap in January 2011 [1] containing an extended list of the relevant studies.

The ability to use language makes our species unique. This ability made the emergence of culture possible which still seems to be a human-specific attribute, and which we like to think of as something that elevates us above other animals. Speech long since has followed us on our evolutionary journey; since so long that substantial physiological apparatus is built around it, like the structures in the central nervous system responsible for communication or the vocal apparatus. It is apparent that words struck their roots in our bodies for a long while but we only recently started to understand how deep exactly these roots reach.

With our words we are capable of sending messages which have involuntary effects on the recipient. These messages are called suggestions.

Results start to crop up confirming that words that we use or hear affect physiological processes, thus healing processes as well. Therefore application of suggestions can be a new adjunct therapeutic tool which also enables us to adjust processes in the body. Because we speak to people during our medical practice we also use suggestions.

In the present paper we would like to highlight what goals can be achieved during medical communication if suggestive properties of words are used consciously. For this purpose empirical results on the effectiveness of therapeutic suggestions in medical practice will be summarized with emphasis on the different areas of application.

\section{Attributes of suggestions, suggestions in medicine}

We send and receive suggestions constantly during our everyday communication. Although suggestions usually manifest verbally, in some situations posture, vocal tone, or silence can also transfer suggestive content.

Everyone is susceptible to suggestions to some extent. Although it shows a variance among people it can be generally stated that specific situational characteristics and the state of mind of the person play a major role in the extent of this susceptibility. The literature defines three specific situations in which suggestibility (the level of responsiveness to suggestions) increases. These are: 
1. altered states of consciousness; 2. fear, defenselessness, extensive emotional strain; 3 . when we cannot rely on our usual frame of reference, because we are in such an unfamiliar situation $[2,3]$.

For people in sickness often more than one of the above is true simultaneously especially in cases of patients in critical conditions [4]. That is why the situation of the patient and the doctor-patient interaction is of utmost importance for suggestive mechanics. Without being familiar with the nature of suggestive communication we might send negative suggestions to the patient with a statement or question that seems perfectly neutral to us, because a person in a negative trance state is disposed to negatively interpret an ambiguous or neutral comment, or to take a communication meant for others personally $[3,5]$.

Although patients are in similar situations resulting from their altered state of consciousness, it is important to state that the most effective communication can be achieved only if we are aware of their personal characteristics and needs, and that positive suggestions are also most efficient this way. (See for example the following studies $[6,7]$.)

In the following we will present those controlled clinical empirical studies which examined the effectiveness of applying positive suggestions around medical procedures and somatic illnesses.

Our aim is to display a comprehensive image of the areas and methods of application of suggestive techniques by reviewing the research literature.

\section{The focus of the review}

We chose a narrow focus for the review so we can present the areas of application of suggestive communication for practitioners who work in somatic medicine with sufficient detail. Hereby we define the boundaries of our investigation:

- Only studies involving patients suffering from "somatic illnesses" will be included in the review, psychiatric or psychological problems are not in the scope of the present study. (Some of the somatization disorders will be mentioned in the papers, because these illnesses are still mostly treated by somatic medicine.)

- Hypnosis is an efficient technique, which increases the susceptibility for suggestions using hypnotic induction, this way suggestions are especially effective if presented during a hypnotic trance state. Hypnosis is applied in numerous studies to "deliver" suggestions to patients with somatic illnesses, none the less we do not focus on these studies. We decided to exclude this area first of all because although hypnotic induction is very effective, there is often no time to use it or environmental settings are not appropriate for it in the everyday practice, and as we stated above practicality and easy accessibility is one of our main concerns. Also there are some excellent reviews which summarize studies using hypnosis in this area, (see for example: [8, 9]). Furthermore a certificate in using hypnotherapy is needed to utilize formal hypnosis, while a shorter training is enough for the application of therapeutic suggestions.

- Using placebo as an adjunct therapy can also be considered as a suggestion technique as the placebo effect can in a large part be attributed to the communication of the anticipated beneficial effects of the medication or therapy [10]. We will not discuss studies involving placebo interventions in this review considering that it is a bit off of our main theme, which are positive suggestions used in the everyday medical communication. This does not mean that placebo would not be used commonly worldwide but the ethical consequences are still highly debated. Contemporary research results and ethical dilemmas of placebo as a therapeutic tool can be found here: $[11,12]$.

- Some relaxation methods can be considered to be suggestion techniques. Relaxation is a commonly used adjunct therapeutic method in medical practice, but during these techniques there are usually no specific suggestions for healing, rather suggestions are aimed to induce rest and calmness. That is why relaxation interventions in general will not be discussed. However, there are illnesses (for example fibromyalgia) in which muscle relaxation is an actual therapeutic goal because it is connected to the illnesses physiological background. Suggestion relaxation methods will only be discussed in these cases. Autogenic training is also a type of relaxation which utilizes suggestions. This technique will not be included in the present review because of its complex psychotherapeutic effects. About the therapeutic effectiveness of autogenic training see the following publications: [13-16].

- Positive suggestions are also used to ease labor. Although childbirth usually takes place in a medical setting, it is not considered a pathological state, so suggestions used around labor do not fit the other studies originating from the "curing medicine" which we will discuss below. For further information on this field see the results of Mamdova et al. [17].

- Finally, the review will only display controlled clinical studies. Case studies or laboratory research done with healthy subjects are not included in our current work.

In the following we will review the empirical research on the use of suggestion techniques in medicine. The 
studies are discussed from two angles: at first we will cover techniques frequently used around medical procedures; in the second part of the paper we will show which suggestion techniques proved to be useful taking specific illnesses as examples.
The list of empirical studies presented in the paper and the overview of their results can be found in Tables I and $I I$.

Table I Studies which found at least one beneficial effect of positive suggestion techniques

\begin{tabular}{|c|c|c|c|}
\hline Reference & $\begin{array}{l}\text { Medical } \\
\text { procedure }\end{array}$ & $\begin{array}{l}\text { Suggestion } \\
\text { intervention }\end{array}$ & Result \\
\hline $\begin{array}{l}\text { Lang and } \\
\text { Berbaum }[18]\end{array}$ & $\begin{array}{l}\text { Radiological } \\
\text { procedures } \\
\text { (arteriography } \\
\text { or percutaneous } \\
\text { nephrostomy) }\end{array}$ & $\begin{array}{l}\text { Training in } \\
\text { suggestive } \\
\text { communication for } \\
\text { the medical team }\end{array}$ & $\begin{array}{l}42 \% \text { lower subjective pain intensity reported in the suggestion } \\
\text { group }(p<0.001) \text { compared to the control; trend showing } 24 \% \\
\text { less analgesic requirement in the suggestion group }(p=0.09)\end{array}$ \\
\hline Lang et al. [6] & $\begin{array}{l}\text { Large core } \\
\text { needle breast } \\
\text { biopsy }\end{array}$ & $\begin{array}{l}\text { Training in } \\
\text { suggestive } \\
\text { communication for } \\
\text { the medical team }\end{array}$ & $\begin{array}{l}\text { Anxiety did not increase in the suggestion group }(p=0.45) \text { while } \\
\text { it increased in the control group }(p<0.001) \text {. Smaller increase in } \\
\text { the pain intensity scores in the suggestion group compared to the } \\
\text { control }(p=0.024)\end{array}$ \\
\hline $\begin{array}{l}\text { Peretz and } \\
\text { Bimstein [19] }\end{array}$ & $\begin{array}{l}\text { Pediatric dental } \\
\text { procedures }\end{array}$ & $\begin{array}{l}\text { Favorite place } \\
\text { imagery, positive } \\
\text { suggestions during } \\
\text { local anesthesia }\end{array}$ & The procedure was more tolerable for the children \\
\hline $\begin{array}{l}\text { McLintock et } \\
\text { al. [20] }\end{array}$ & Hysterectomy & $\begin{array}{l}\text { Taped suggestions } \\
\text { during general } \\
\text { anesthesia }\end{array}$ & $\begin{array}{l}\text { Patients in the suggestion group consumed } 14.6 \mathrm{mg}(22.4 \%) \text { less } \\
\text { morphine compared to the control on the first day after surgery }\end{array}$ \\
\hline $\begin{array}{l}\text { Nilsson et al. } \\
{[21]}\end{array}$ & Hysterectomy & $\begin{array}{l}\text { Tape containing } \\
\text { suggestions } \\
\text { combined with } \\
\text { music played during } \\
\text { surgery }\end{array}$ & $\begin{array}{l}8.7 \mathrm{mg}(25 \%) \text { less analgesic medication (ketobemidone) was used } \\
\text { on the day of surgery }(p=0.01) \text { in comparison with the control } \\
\text { group. (No difference in the } 1 \mathrm{st}, 2 \text { nd and } 3 \text { rd postoperative } \\
\text { days.) Lower fatigue scores }(p<0.001) \text { at the end of hospital } \\
\text { stay (no difference on the day of the surgery and one day after } \\
\text { the operation). (There was no difference between the groups in } \\
\text { mobilization, nausea and vomiting, bowel functions, subjective } \\
\text { well-being and length of hospital stay) }\end{array}$ \\
\hline Lambert [22] & $\begin{array}{l}\text { Surgery } \\
\text { with general } \\
\text { anesthesia }\end{array}$ & $\begin{array}{l}\text { Guided imagery } \\
\text { training for the } \\
\text { participants } \\
\text { (children) }\end{array}$ & $\begin{array}{l}\text { The length of post-surgical hospital stay was shorter by } 19 \text { hours } \\
(14 \%) \text { in the suggestion group }(p<0.05) \text { and they experienced } \\
11 \% \text { less pain on the days after the operation. (No difference } \\
\text { in analgesic medication requirement, length of the procedure, } \\
\text { length of anesthesia, length of stay in the post-anesthesia care unit } \\
\text { (PACU) and in the level of postoperative anxiety) }\end{array}$ \\
\hline $\begin{array}{l}\text { Disbrow et al. } \\
{[7]}\end{array}$ & $\begin{array}{l}\text { Major } \\
\text { intraperitoneal } \\
\text { surgery }\end{array}$ & $\begin{array}{l}\text { Tape containing } \\
5 \text { minutes of } \\
\text { suggestion } \\
\text { intervention } \\
\text { targeting } \\
\text { postoperative bowel } \\
\text { motility }\end{array}$ & $\begin{array}{l}\text { Bowel function restored } 1.6 \text { days earlier }(p<0.05) \text { and a trend } \\
\text { was uncovered showing that the first fluid intake also came } 1.5 \\
\text { days earlier }(p=0.1) \text { in the suggestion group. (There was no } \\
\text { difference in the time to the removal of the nasogastric tube and } \\
\text { the length of hospital stay) }\end{array}$ \\
\hline $\begin{array}{l}\text { Enqvist et al. } \\
{[23]}\end{array}$ & $\begin{array}{l}\text { Maxillofacial } \\
\text { surgery }\end{array}$ & $\begin{array}{l}\text { Taped suggestions } \\
\text { played during } \\
\text { surgery }\end{array}$ & $\begin{array}{l}\text { Lower blood pressure }(p=0.032) \text {, shorter period of pyrexia }(p \\
=0.05) \text {, and a trend for less blood loss }(p=0.065) \text { was reported } \\
\text { in the suggestion group who also received hypnotherapy before } \\
\text { the surgery. The group who only received the taped suggestions } \\
\text { during the operation experienced faster recovery }(p=0.025) \text {, } \\
\text { lower blood pressure }(p=0.002) \text { and a trend for lower heart } \\
\text { rate }(p=0.098) \text { as well compared to the control group. (There } \\
\text { was no difference in postoperative analgesic and anxiolytic drug } \\
\text { requirement between the groups) }\end{array}$ \\
\hline
\end{tabular}


Table I (continued)

\begin{tabular}{|c|c|c|c|}
\hline Reference & $\begin{array}{l}\text { Medical } \\
\text { procedure }\end{array}$ & $\begin{array}{l}\text { Suggestion } \\
\text { intervention }\end{array}$ & Result \\
\hline $\begin{array}{l}\text { Evans and } \\
\text { Richardson } \\
{[24]}\end{array}$ & Hysterectomy & $\begin{array}{l}\text { Taped suggestions } \\
\text { during general } \\
\text { anesthesia }\end{array}$ & $\begin{array}{l}\text { The study showed } 1.3 \text { days }(16 \%, p<0.002) \text { shorter } \\
\text { postoperative hospital stay, } 22 \text { hours }(45 \%, p<0.005) \text { shorter } \\
\text { pyrexia, and better than expected recovery }(p<0.002) \text { in the } \\
\text { suggestion group compared to the control. (No difference in } \\
\text { the amount of postoperative analgesics used, the level of pain } \\
\text { unpleasantness (on the } 5 \text { th postoperative day), time required for } \\
\text { mobilization, urinary problems, incidence of nausea and vomiting } \\
\text { and in mood and anxiety scores) }\end{array}$ \\
\hline
\end{tabular}

Jelicic et al. Hysterectomy Suggestion tape [25]

Bonke et al. Gallbladder [26] surgery

Lebovits et al. Hernia repair [28]

Jayaraman et al. [29]

Williams et al. Mayor [30]

Jakubovits et al. [32]

Jakubovits et al. [33]
Operation with general anesthesia

gynecological surgery

Gynecological surgery with general anesthesia

Gynecological surgery with general anesthesia during general anesthesia

Suggestion tape during general anesthesia

Suggestion tape during general anesthesia

Taped suggestions combined with music or only music during general anesthesia

Suggestion tape during general anesthesia

Suggestions before and during surgery

Suggestions before and during surgery
Members of one of the suggestion groups spent less time in the hospital after surgery. (No difference in subjective well-being in any of the suggestion groups compared to the control and in the length of hospital stay in the other two suggestion groups)

A tendency showing that members of the suggestion group had a shorter hospital stay $(p=0.059)$. Reanalysis of the data showed that for participants over 55 years of age the suggestion tape was a protective factor against prolonged hospital stay $(p=0.0059)$. (No difference in the amount of analgesics used after surgery, subjective pain intensity, subjective well-being, nausea, vomiting and quality of postoperative recovery)

Suggestion group patients experienced less nausea and vomiting in the first 90 minutes after surgery compared to control patients $(p<0.002)$ (there was no difference in the rest of the day). Incidence of headaches $(p<0.003)$ and muscle discomfort also decreased $(p<0.002)$. (Pain intensity and analgesic medication requirement was the same in the two groups)

Less pain $(p<0.001)$ and fatigue $(p<0.001)$, and better subjective well-being $(p<0.001)$ was observed in the suggestion group compared to the regular treatment control, but no difference was found in comparison with the music only group

24 hours after surgery the incidence of vomiting was $32 \%$ in the suggestion group while it was $69 \%$ in the control group $(p<0.05)$. The severity of vomiting was lower, too $(p<0.05)$, and suggestion group patients needed in average $7 \mathrm{mg}(36 \%)$ less metoclopramide. (No difference was found between the groups in blood loss, fluid intake, postoperative analgesic requirements and length of anesthesia)

Reduced anxiety $(p=0.014)$ and pain $(p=0.01)$, and better wellbeing was recorded $(p=0.0027)$ while medication requirement also decreased. [No positive effect was found on subjective and objective outcomes of recovery (wound healing, complications, length of hospital stay, healing quality judged by doctors, nurses and patients); other physiological factors (bowel motility, urinary problems, body temperature); and on the following variables: headache, dizziness, appetite, mobility, wakefulness ]

Lower pain scores on the day of surgery $(p=0.02), 34 \%$ lower pain medication requirement on the first six days after the operation $(p=0.02)$, and quicker recovery 5 hours $(p<0.04)$, 4 days and 5 days postoperatively $(p=0.01$ and $p=0.03$, respectively) was reported in the suggestion group. Appetite $(p<0.02)$ and bowel motility $(p<0.02)$ also returned sooner in this group 
Table I (continued)

\begin{tabular}{|c|c|c|c|}
\hline Reference & $\begin{array}{l}\text { Medical } \\
\text { procedure }\end{array}$ & $\begin{array}{l}\text { Suggestion } \\
\text { intervention }\end{array}$ & Result \\
\hline $\begin{array}{l}\text { Szilágyi et al. } \\
{[43]}\end{array}$ & $\begin{array}{l}\text { Intensive } \\
\text { care unit, } \\
\text { mechanically } \\
\text { ventilated } \\
\text { patients }\end{array}$ & $\begin{array}{l}20 \text { minutes of } \\
\text { psychological } \\
\text { support involving } \\
\text { suggestions daily }\end{array}$ & $\begin{array}{l}\text { The time of mechanical ventilation was } 2.5 \text { days shorter in the } \\
\text { group getting suggestion intervention }(p<0.04) \text { and in one of } \\
\text { the two participating hospitals length of stay in the ICU was } \\
\text { also reduced by } 4 \text { days }(p<0.02) \text {. (Length of stay did not differ } \\
\text { among the groups in the other hospital) }\end{array}$ \\
\hline $\begin{array}{l}\text { Edelson and } \\
\text { Fitzpatrick } \\
{[44]}\end{array}$ & $\begin{array}{l}\text { Various chronic } \\
\text { pain disorders }\end{array}$ & $\begin{array}{l}\text { Cognitive behavioral } \\
\text { therapy applying } \\
\text { positive suggestions }\end{array}$ & $\begin{array}{l}\text { Thanks to the intervention, pain intensity decreased }(p<0.01) \text {, } \\
\text { and the amount of active hours (standing, walking) increased } \\
(p<0.01) \text { contrary to the time spent passively (sitting), which } \\
\text { decreased }(p<0.001) \text {. (There was no difference in the time spent } \\
\text { lying down and the assessment of pain) }\end{array}$ \\
\hline $\begin{array}{l}\text { Derbyshire et } \\
\text { al. }[45]\end{array}$ & Fibromyalgia & Guided imagery & $\begin{array}{l}\text { Imagery suggestions were successful in controlling pain intensity } \\
(p<0.001)\end{array}$ \\
\hline $\begin{array}{l}\text { Castel et al. } \\
{[46]}\end{array}$ & Fibromyalgia & $\begin{array}{l}\text { Relaxation } \\
\text { suggestions }\end{array}$ & $\begin{array}{l}\text { Relaxation suggestions decreased subjective pain intensity by } \\
43 \%(p<0.01) \text {. The sensory dimension of pain decreased by } 27 \% \\
(p<0.01) \text {, and the affective component by } 53 \%(p<0.001)\end{array}$ \\
\hline Thomas [47] & $\begin{array}{l}\text { General } \\
\text { practitioner } \\
\text { consultation, } \\
\text { somatization } \\
\text { disorders }\end{array}$ & $\begin{array}{l}\text { Consultation } \\
\text { involving positive } \\
\text { suggestions }\end{array}$ & $\begin{array}{l}64 \% \text { of patients in the group getting positive consultation got } \\
\text { better one week later, significantly more, than in the negative } \\
\text { consultation group in which only } 39 \% \text { reported the same } \\
(p<0.001)\end{array}$ \\
\hline $\begin{array}{l}\text { Spanos et al. } \\
{[48]}\end{array}$ & Wart therapy & $\begin{array}{l}\text { Positive suggestion } \\
\text { intervention on two } \\
\text { occasions }\end{array}$ & $\begin{array}{l}\text { The incidence of spontaneous wart remission was higher in the } \\
\text { suggestion group compared to the control }(p<0.01)\end{array}$ \\
\hline $\begin{array}{l}\text { Cowan et al. } \\
{[27]}\end{array}$ & Bariatric surgery & $\begin{array}{l}\text { Suggestion tape } \\
\text { during general } \\
\text { anesthesia and in the } \\
\text { recovery room }\end{array}$ & $\begin{array}{l}\text { The suggestion group had better scores in the postoperative } \\
\text { recovery regimen }(p<0.05) \text {, they required less encouragement } \\
\text { to perform specific tasks }(p<0.05) \text {, and were discharged } 1.6 \text { days } \\
\text { earlier from the hospital }(p<0.01) \text { than the controls }\end{array}$ \\
\hline $\begin{array}{l}\text { Eberhart et al. } \\
{[31]}\end{array}$ & Thyroidectomy & $\begin{array}{l}\text { Suggestion tape } \\
\text { during general } \\
\text { anesthesia }\end{array}$ & $\begin{array}{l}\text { Patients in the suggestion group experienced less postoperative } \\
\text { nausea and vomiting }(p<0.005) \text {, required less anti-emetic } \\
\text { treatment }(p<0.005) \text {. (There was no difference in analgesic drug } \\
\text { consumption) }\end{array}$ \\
\hline $\begin{array}{l}\text { Cruise et al. } \\
{[53]}\end{array}$ & Cataract surgery & $\begin{array}{l}\text { Relaxing suggestions } \\
\text { played during the } \\
\text { operation }\end{array}$ & $\begin{array}{l}\text { State anxiety decreased compared to presurgery baseline in the } \\
\text { suggestion group }(p<0.05) \text {, they felt more relaxed }(p<0.005) \\
\text { than groups getting white noise and operating room noise [but } \\
\text { these were also true for the relaxing music group }(p<0.05)] \text {. } \\
\text { (There was no beneficial effect on any of the registered } \\
\text { physiological measures, and the reported nervousness of the } \\
\text { patients) }\end{array}$ \\
\hline
\end{tabular}

\section{Results}

\section{Positive suggestions used during medical procedures}

Relieving procedural pain

In spite of their curing or diagnostic purposes some of the medical procedures can be unpleasant or outright painful for the patient. This kind of pain is referred to as procedural pain in the literature because they are evoked by medical interventions.

Patients are more cooperative and the general adherence is better if they do not experience pain during the procedure. In many cases pain can be prevented, reduced or relieved with the application of positive suggestive communication with the patient. Lang and Berbaum [18] developed a training for radiology personnel during which the participants in the training learned the correct use of positive communication, suggestions, diversion and how to build rapport. They also acquired experience in using relaxation and self-hypnosis techniques. During the study they interviewed 96 patients 
Table II | Studies which found no evidence of the beneficial effects of positive suggestions

\begin{tabular}{|c|c|c|c|}
\hline Reference & $\begin{array}{l}\text { Medical } \\
\text { procedure }\end{array}$ & $\begin{array}{l}\text { Suggestion } \\
\text { intervention }\end{array}$ & Result \\
\hline $\begin{array}{l}\text { Block et al. } \\
{[34]}\end{array}$ & $\begin{array}{l}\text { Various } \\
\text { abdominal } \\
\text { surgeries }\end{array}$ & $\begin{array}{l}\text { Suggestion tape } \\
\text { during general } \\
\text { anesthesia }\end{array}$ & $\begin{array}{l}\text { No difference was found between the suggestion and control } \\
\text { groups in the frequency of consumption and the dosage of } \\
\text { postoperative analgesic and antiemetic drugs; in pyrexia, nauseam } \\
\text { and vomiting; in the incidence of other gastrointestinal or } \\
\text { urinary complaints; in the levels of pain, anxiety, physiological or } \\
\text { psychological recovery; and in the length of hospital stay after the } \\
\text { operation }\end{array}$ \\
\hline
\end{tabular}

$\begin{array}{lll}\text { Dawson et al. Hysterectomy } & \begin{array}{l}\text { Suggestion tape } \\ \text { during general }\end{array} & \begin{array}{l}\text { No difference between the groups in analgesic and antiemetic } \\ \text { drug requirement; and in the level of pain, and nausea }\end{array}\end{array}$

Melzack et al. Gallbladder Suggestion tape

[36] surgery or during general
hysterectomy anesthesia

The suggestion and control groups did not differ in their reported pain intensity in the first four postoperative days, and contrary to the expectations control group patients spent in average 17 hours less in the hospital than the suggestion group $(p<0.05)$

Blankfield et Coronary artery Suggestion tape al. [37] bypass surgery during general Time spent in the post-anesthesia care unit (PACU) and in the anesthesia and after recovery scores, daily activity and cardiovascular problems were surgery the same in the control and the suggestion group. None the less half of the patients in the suggestion group claimed that the intervention tape helped them in some way Van der Laan
et al. [38]

Liu et al. [41] Hysterectomy

Boeke et al. [39] myomectomy, laparotomy
Hysterectomy, or gynecologic

Suggestion tape during general anesthesia

\section{Suggestion} intervention before and after surgery

The groups did not show difference in postoperative morphine consumption, pain intensity, length of hospital stay, and nausea and anxiety scores

No difference was reported between the groups in the length of postoperative pyrexia, subjective pain intensity, the amount of analgesics used, the number of nausea episodes, flatulence, mobility, wound or other complications and length of hospital stay

The suggestion and control groups did not differ in subjective pain intensity, length of hospital stay, level of nausea, subjective wellbeing and in the level of recovery assessed by the medical staff undergoing radiological procedures (radiological arteriography or percutaneous nephrostomy) about their pain experience. Half of the patients had the procedure before, the other half of them after the training of the radiology staff. The results of the study showed that after the training patients reported about half the amount of pain compared to patients who had their procedure before the training. Researchers also found a trend indicating that less pain medication was used after the training. Lang et al. [6] tested the effectiveness of a training based on similar suggestive techniques in a more recent study: 236 patients enlisted for large core needle breast biopsy were randomized to a standard treatment, an empathic treatment or a hypnosis group. The standard treatment group received only regular medical care. For our present purposes the empathic treatment group is the most interesting. In this group - aside from the usual hospital staff - a medical assistant trained in a standard behavioral pattern was also present during the procedure. This behavioral pattern included matching the patients verbal and nonverbal communication, attentive listening, increasing the patient's perception of control (for example: "let us know at any time what we can do for you"), rapid response to the needs of the patient, encouragement and the avoidance of negative communication, instead of which neutral phrases were used, like: instead of "you will feel a burn and a sting", "this is the local anesthetic".

Patient anxiety did not increase in the empathic treatment group during the intervention (contrary to the standard treatment group), and they reported less pain than the regular treatment control. Another important finding is that both the length and the total cost of the procedure was identical in the two groups in spite the fact that an additional professional was present in the case of the empathic treatment group (this can be at- 
tributed to the lower number of complications in the empathic treatment group). We should note here that in this study we are not only talking about positive phrasing of sentences rather a technique largely customized to the needs of the patient.

We can also find similar encouraging results in the field of pediatric dentistry. Peretz and Bimstein [19] applying a suggestive imagery technique asked the patients to select a favorite, calm place and later - during the injection - they helped them in imagining this place as vividly as possible. Thanks to this method the otherwise really unpleasant intervention got more bearable for the patients.

\section{Suggestion techniques in surgery}

One of the most extensively studied areas of suggestive techniques is their application in relieving surgical pain. A good example is the research of McLintock et al. [20] in which they worked with 63 patients enlisted for elective hysterectomy. Patients were allocated into two groups. Participants in the intervention group listened to a tape under general anesthesia containing positive suggestions prepared specifically for this procedure. The script of the intervention contained for example the following suggestions: "Everything is going very well, we're very pleased with your progress"; "You feel warm and comfortable, calm, and relaxed"; "Any pain that you feel after the operation will not concern you." For the members of the control group a blank tape was played. The researchers report that women who heard the suggestions needed less morphine from the first hour after the operation compared to those who listened to the blank tape, and this difference only got larger in the first 24 hours after the procedure. $14.6 \mathrm{mg}(22.4 \%)$ less morphine was used in the intervention group compared to the control.

Nilsson et al. [21] also report positive results using a similar study protocol. The group getting positive suggestions combined with music under general anesthesia needed in average $26.6 \mathrm{mg}$ less ketobemidone after the operation. (The mean of pain medication used in the control group was $35.3 \mathrm{mg}$.)

Other researchers confirmed the analgesic effects of positive suggestions as well (see also [22]), but not only pain can be effectively treated with suggestive techniques.

The return of bowel motility can also be supported by this method: Disbrow et al. [7] randomized 40 patients waiting for intestinal operations into two groups. They prepared a 5-minute recording for both groups which contained personalized elements, information about the surgery and postsurgical instructions. The personalized content came from a previous interview (for example the mention of favorite food or the name of a family member). The recording of the suggestion group contained a script enhancing the restoration of bowel motility after surgery: "Because you need to eat food to bring nutrients to your body, it is important that your stomach and intestines begin to move as soon as possible after your operation. Abdominal operations cause your stomach and intestines to stop moving for a short time. In your case, this will be kept to a minimum because you will be very relaxed and comfortable. Your stomach will pump and gurgle, and you will become very hungry soon after the operation. Therefore, your stomach and intestines will begin to move and churn so that you can eat (favorite food from earlier in interview) soon after the operation." (pp. 489) The researchers found that in the positive suggestion group bowel motility restored 1.6 days earlier.

Methodically correct controlled studies also demonstrate that by using suggestive techniques blood loss during surgery can be cut back by $30 \%$ [23], that length of stay in the hospital can be reduced [23-27], and that the occurrence of postoperative nausea, vomiting [2831] headaches and muscle discomfort [28] is lowered as well.

A study conducted by a Hungarian research group also confirmed the beneficial effects on the outcomes mentioned above. Jakubovits et al. [32, 33] gave positive suggestions to the patients before and during the operation. They studied 51 women in their first project and found that those who got positive suggestions both before and during the operation reported less pain and required less analgesics, they had lower anxiety and felt generally better compared to the control group who only got regular treatment. Forty-six patients participated in their second study. Suggestion group patients had lower pain intensity on the day of the surgery and they needed $34 \%$ less pain medication in the first 6 postoperative days. There were also less postoperative complaints in this group and their appetite and bowel motility restored faster (75\% of suggestion group patients were eating well already at the second postoperative day). In this study every patient received a unique suggestion protocol before the operation using the following guidelines: 1. minimizing fear of the unknown by providing information; 2. reducing anxiety by relaxation (for example using the calm place technique); 3 . increasing the feeling of control in the patient by providing choice (for example they could choose which finger they wanted the pulse-oximeter to be clipped on); 4 . increasing activity to enhance healing processes (for example providing instructions on the possible post-operative activities); 5. direct suggestions (for example: “your appetite will return soon after the procedure").

Above we summarized which outcomes can be positively affected by the use of suggestive communication in surgical preparation, during surgery and around other types of unpleasant medical procedures. 
Although there is substantial evidence supporting the effectiveness of suggestion techniques used around surgical procedures, there is also a number of publications which report no substantial effect. There was no difference in pain relief and analgesics used between the control and intervention groups in the following studies: [26, 28, 31, 34-39]. Nilsson et al. [40] and Jayaraman et al. [29] did manage to show significant effect in pain related outcome measures compared to the regular treatment control group, but there was no difference in comparison to the group getting music as an active control condition. The following papers report nullresults concerning outcomes of postoperative recovery (like length of stay in the hospital): $[34,37,39,41]$. There are also studies in which nausea and vomiting was not significantly reduced compared to the control group $[21,26,34,35,38,39]$.

Intensive care unit

Another group of Hungarian researchers assessed the effects of suggestions when utilized in the intensive care unit (ICU). Applying the method developed by Varga et al. [42], in the study of Szilágyi et al. [43] patients in the intervention group got a positive suggestion intervention while the control group was treated regularly. Patients in the intervention group were visited by professionals (physicians or psychologists) trained in using Psychological Support Based on Positive Suggestions (PSBPS), a technique specifically focused on applying suggestive techniques in medical settings. These professionals talked to the patients every day for 20 minutes. This 20 -minute long visit contained a semi-structured intervention: the caregivers had a number of pre-prepared scripts in their toolkit, but other than this every intervention was unique and personalized. One of the standard scripts goes like this: The most important thing has already happened: you are in a ward where everything is available for you to get the best treatment. In your case this means basically (here we should state positively the aim of the treatment). Doctors, nurses and all these fantastic machines around you are just to belp your body to regain the balance for its harmonious functioning [42]. The intervention continued until the patient left the ICU.

The study revealed that patients in the intervention group required 2.5 days shorter mechanical ventilation and the length of stay in the ICU was reduced by 4 days compared to the control group. An interesting aspect of the results was that the intensive care units which participated in the study differed from each other in the efficiency of the suggestive intervention. The researchers point out that one of the characteristic differences between the two wards was that patients were treated by the same caregiver with PSBPS in more than $50 \%$ of the sessions in one of them, while persons performing the treatment alternated more often in the other ICU. Results show that beneficial effects of the suggestive intervention like shorter ventilation time and shorter length of stay were only pronounced in the group of patients who were treated by the same caregiver most of the time, while no beneficial effects were significant with patients who had alternating caregivers.

\section{Suggestion techniques in treating specific illnesses}

\section{Chronic pain}

Edelson and Fitzpatrick [44] studied 27 patients suffering from various chronic pain disorders. They evaluated the effectiveness of a type of cognitive behavioral therapy (CBT) for pain control. This method contained several positive suggestion elements, like it encouraged patients to avoid using the word "pain" during the expressing of their experiences, and to use imagery techniques to reinterpret these feelings as "numbness". They were also taught to identify and positively reframe negative inner speech.

Significant increase in activity level (measured through 3 days after the last session) and decrease in pain intensity (measured at the end of the last session) was found in the CBT group. In this study hypnosis was also applied in one of the intervention groups. Although treatment with hypnosis also yielded improved pain ratings after the $4^{\text {th }}$ session, interestingly it did not increase the activity level of patients like CBT alone. One of the reasons for this could be that patients might have attributed their improvements to hypnosis induction itself which is not that easily transferred to their daily routines as techniques learned during the cognitive therapy.

\section{Fibromyalgia}

Empirical studies confirm that positive suggestion techniques can be effectively used in the treatment of fibromyalgia.

Derbyshire et al. [45] included 13 highly hypnotizable fibromyalgia patients in their study, who learned an imagery technique. When so instructed, the subjects had to imagine their fibromyalgia pain in a dial then they "took control" of the dial, this way being able to increase or decrease their fibromyalgia pain at will. (This study also contained a hypnosis condition. In the hypnotic state, pain control was better using the above-mentioned imagery.)

Castel et al. [46] evaluated 3 methods for decreasing fibromyalgia pain. The 45 participants were allocated to three groups: in the first one, patients got suggestions specifically to decrease their pain under hypnosis, in the second one the hypnotic suggestions involved relaxation and 
calmness instead of pain relief, and the third group got relaxation suggestions without hypnosis. The researchers found that all three interventions decreased fibromyalgia pain. Suggestions for pain relief were the most efficient, and there was no difference in the pain scores between the two groups getting relaxation suggestions.

\section{Somatization}

Somatization disorders are common in the office of the general practitioner. These patients have symptoms that elicit significant suffering but physicians cannot find any physiological or organic cause for the symptoms. Thomas [47] conducted a study involving 200 patients with symptoms but no abnormal physical signs and for whom no definite diagnosis could be made. The participants were randomly selected to attend one of four standardized consultations. They either received positive or negative consultation with or without treatment. The results showed that of patients who got positive consultation (in these groups the patient was given a firm diagnosis and told confidently that he would be better in a few days, pp. 1200), 64\% felt better in two weeks, conversely only $39 \%$ of those getting negative consultation (in which no firm assurance was given) reported getting better.

Warts

Based on their results Spanos et al. [48] concluded that positive suggestions facilitate the treatment of warts as well. Members of the intervention group received positive suggestions at two occasions, while the control group got no treatment. During the suggestion sessions patients were asked to focus their attention inward and they were told that the skin around the wart starts to tingle and to get warmer. The dermatologist applying the intervention also informed the patients that their wart will get smaller and smaller and it will fall off. He asked the subjects to imagine vividly that their wart starts to shrink and disappears. Hypnosis induction preceded the suggestions in the first intervention group, relaxation in the second and in the third there were no adjunct methods, only the above-mentioned suggestions. The intervention was most efficient in the latter (suggestions only) group. After the 6-week follow-up period one-third of the participants from this group lost at least one wart from their hand, while there was no spontaneous healing in the control group.

\section{Discussion}

There are a large number of controlled clinical studies aiming to evaluate the effectiveness of positive suggestion techniques used adjunctively in the treatment of somatic illnesses.

These methods - because they mostly apply the tools of everyday communication - are easily learned and can be utilized in day to day medical practice without additional costs.

That trained and conscious use of positive suggestions is not yet wide-spread in medicine can in part be explained by the fact that clinical significance of positive communication was only started to be uncovered in the last decades.

There are encouraging results coming from multiple areas of medicine already. We could see that in many occasions suggestion techniques used as adjunct to medical procedures led to a faster and more efficient healing process, furthermore, they contributed to the reduction of pain and the unpleasant side-effects of medical procedures, but the results are still ambiguous.

Our picture of this topic is far from being complete. First of all, most of the studies still originate from surgery. It would be necessary to replicate the results of studies conducted in non-surgical settings and to perform studies with the goal of uncovering the underlying mechanisms of the effects.

We have listed several studies which did not support the hypothesis that suggestions have a significant positive effect in the perioperative period, but in other medical settings we could only find studies reporting positive results. This could be an indication of publication bias (meaning that studies reporting null-results or negative results did not get published). On the other hand this also poses a scientifically relevant problem: Which of the suggestion techniques yield the positive results and which characteristics reduced the effectiveness in other studies? We encourage the publication of detailed suggestion scripts and protocols, as a scientifically correct analysis and comparison would only be possible this way.

Based on the reported protocols and results of the reviewed papers it seems that personalization of suggestive therapy can be a key factor in efficiency. Techniques in which suggestions were delivered in person, thus allowing a caregiver to emphatically adapt the technique to the patients' needs; suggestion scripts containing personally relevant content; and studies in which patients were awake during the psychological intervention seem to be more effective than protocols which gave no room for personalization (patients under general anesthesia, recorded intervention, no content related to the person).

One of the basic goals during a scientific investigation is usually the strict control of as many confounding variables as possible, so it may seem a good idea to standardize the suggestion script or to record it so every person gets the same intervention. Although we are fully aware that control and comparability in research makes standardization of the intervention necessary, in light of our review researchers also have to take into consideration 
that there might be a tradeoff between methodological quality (standardization) and effectiveness (personalization).

Our conclusion also holds true for clinical application. In this case simple positive rephrasing of our message is only the first step. As stated above suggestive communication reaches its maximal potential if both the specific needs of the patient is considered and the rules of designing positive suggestions are applied [49, 50]. (Good examples can be found here: [51, 52].)

Although our review primarily focused on verbally transmitted positive suggestions (because of the predominance of these kinds of studies) we have to remember that not all suggestions are verbal. The hospital environment, the communication setting, and of course nonverbal communication also carry suggestions so in practice these have to be accounted for as well.

We believe that professional use of positive communication is of outmost importance as all medical communication is suggestive. If we utilize this consciously we can enhance healing and the comfort of the patients. As demonstrated in several of the above-described studies these skills and techniques can be learned. In Hungary medical communication is the part of the education of doctors and since the last years the curriculum contains suggestive techniques, too [49]. Aside from this, there is also a training on the use of suggestions specifically for medical employees. The training was started in 2001 and since then until 2012 almost 200 professionals graduated. It would be beneficial both for medical professionals and for patients if trainings in this field would get even more emphasis.

In summary, suggestive communication is another still underutilized - tool in our arsenal which has the potential to significantly affect the everyday practice and effectiveness of modern medicine. To harness this tool to the fullest a lot of work still needs to be done by researchers, by the practicing doctors and nurses and by people involved in their education and training.

\section{References}

1. Kekecs Z, Varga K: Pozitív szuggesztiós technikák a szomatikus orvoslásban [Positive suggestion techniques in somatic medicine] Orv Hetil 152, 96-106 (2011) [Hungarian]

2. Diószeghy C, Varga K, Fejes K, Pénzes I: Pozitív szuggesztiók alkalmazása az orvosi gyakorlatban: tapasztalatok az intenzív osztályon [Use of positive suggestions in medical practice: experiences in the intensive care unit]. Orv Hetil 141, 1009-1013 (2000) [Hungarian]

3. Varga K: Szuggesztív hatások az orvosi gyakorlatban, különös tekintettel a perioperatív időszakra [Suggestive effects in medical practice, and especially in the perioperative period]. Psychiatria Hungarica 13, 529-540 (1998) [Hungarian]

4. Cheek DB: Communication with the critically ill. Am J Clin Hypn $12,75-85$ (1969)

5. Bejenke CJ (1996): Preparation of patients for stressful medical interventions. Some simple principles. In: Munich Lectures on
Hypnosis and Psychotherapy, eds Peter B, Trenkel B, Kinzel FC, Duffner C, Iost-Peter A, M.E.G.-Stiftung, München, pp. 27-36

6. Lang EV, Berbaum KS, Faintuch S, Hatsiopoulou O, Halsey N, Li X, Berbaum ML, Laser E, Baum J: Adjunctive self-hypnotic relaxation for outpatient medical procedures: A prospective randomized trial with women undergoing large core breast biopsy. Pain 126, 155-164 (2006)

7. Disbrow EA, Bennett HL, Owings JT: Effect of preoperative suggestion on postoperative gastrointestinal motility. West J Med $158,488-492(1993)$

8. Pinnell CM, Covino NA: Empirical findings on the use of hypnosis in medicine: A critical review. Int J Clin Exp Hypn 48, 170-194 (2000)

9. Lynn SJ, Kirsch I, Barabasz A, Cardeña E, Patterson D: Hypnosis as an empirically supported clinical intervention: The state of the evidence and a look to the future. Int J Clin Exp Hypn 48, 239-259 (2000)

10. Varga K: Placebó és szuggesztió - a gyógyítás szolgálatában [Placebo and suggestion - for the benefit of patients]. Magyar Pszichológiai Szemle 61, 597-616 (2006) [Hungarian]

11. Köteles F, Fodor D, Cziboly Á, Bárdos Gy: A placebo terápiás felhasználásának etikai kérdései [Ethical problems in the therapeutic use of placebo]. Magyar Pszichológiai Szemle 62, 429-448 (2007) [Hungarian]

12. Benedetti F (2009): Placebo effects. Understanding the mechanisms in health and disease. Oxford University Press, Oxford

13. Rucco V, Feruglio C, Genco F, Mosanghini R: [Autogenic training versus Erickson's analogical technique in treatment of fibromyalgia syndrome]. Riv Eur Sci Med Farmacol 17, 41-50 (1995) [Italian]

14. Stetter F, Kupper S: Autogenic training: A meta-analysis of clinical outcome studies. Appl Psychophysiol Biofeedback 27, 45-98 (2002)

15. Aivazyan TA, Zaitsev VP, Yurenev AP: Autogenic training in the treatment and secondary prevention of essential hypertension: Five-year follow-up. Health Psychol 7 Suppl, 201-208 (1988)

16. Blanchard EB, Khramelashvili VV, McCoy GC, Aivazyan TA, McCaffrey RJ, Salenko BB, Musso A, Wittrock DA, Berger M, Gerardi MA et al.: The USA-USSR collaborative cross-cultural comparison of autogenic training and thermal biofeedback in the treatment of mild hypertension. Health Psychol 7 Suppl, 175-192 (1988)

17. Mamdova GM, Zhakhmalova IA, Makashvili LG: [The effectiveness of complex psychological preparation for delivery of pregnant women]. Georgian Med News 166, 17-21 (2009) [Russian]

18. Lang EV, Berbaum KS: Educating interventional radiology personnel in nonpharmacologic analgesia: effect on patients' pain perception. Acad Radiol 4, 753-757 (1997)

19. Peretz B, Bimstein E: The use of imagery suggestions during administration of local anesthetic in pediatric dental patients. ASDC J Dent Child 67, 263-267 (2000)

20. McLintock TT, Aitken H, Downie CF, Kenny GN: Postoperative analgesic requirements in patients exposed to positive intraoperative suggestions. BMJ 301, 788-790 (1990)

21. Nilsson U, Rawal N, Uneståhl LE, Zetterberg C, Unosson M: Improved recovery after music and therapeutic suggestions during general anaesthesia: A double-blind randomised controlled trial. Acta Anaesthesiol Scand 45, 812-817 (2001)

22. Lambert SA: The effects of hypnosis/guided imagery on the postoperative course of children. J Dev Behav Pediatr 17, 307-310 (1996)

23. Enqvist B, von Konow L, Bystedt H: Pre- and perioperative suggestion in maxillofacial surgery: Effects on blood loss and recovery. Int J Clin Exp Hypn 43, 284-294 (1995)

24. Evans C, Richardson PH: Improved recovery and reduced postoperative stay after therapeutic suggestions during general anaesthesia. Lancet 2, 491-493 (1988) 
25. Jelicic M, Bonke B, Millar K: Effect of different therapeutic suggestions presented during anaesthesia on post-operative course. Eur J Anaesthesiol 10, 343-347 (1993)

26. Bonke B, Schmitz PI, Verhage F, Zwaveling A: Clinical study of so-called unconscious perception during general anaesthesia. Br J Anaesth 58, 957-964 (1986)

27. Cowan GS Jr, Buffington CK, Cowan GS 3rd, Hathaway D: Assessment of the effects of a taped cognitive behavior message onpostoperative complications (therapeutic suggestions under anesthesia). Obes Surg 11, 589-593 (2001)

28. Lebovits AH, Twersky R, McEwan B: Intraoperative therapeutic suggestions in day-case surgery: Are there benefits for postoperative outcome? Br J Anaesth 82, 861-866 (1999)

29. Jayaraman L, Sharma S, Sethi N, Sood J, Kumar VP: Does intraoperative music therapy or positive therapeutic suggestions during general anaesthesia affect the postoperative outcome? - A double blind randomised controlled trial. Indian J Anaesth 50, 258-261 (2006)

30. Williams AR, Hind M, Sweeney BP, Fisher R: The incidence and severity of postoperative nausea and vomiting in patients exposed to positive intra-operative suggestions. Anaesthesia 49, 340-342 (1994)

31. Eberhart LH, Döring HJ, Holzrichter P, Roscher R, Seeling W: Therapeutic suggestions given during neurolept-anaesthesia decrease post-operative nausea and vomiting. Eur J Anaesthesiol 15 446-452 (1998)

32. Jakubovits E, Janecskó M, Varga K: Mútét előtti-alatti szuggesztiók hatása a betegek posztoperatív állapotára [The effects of pre- and perioperative suggestions on the postoperative course] Aneszteziológia és Intenzív Terápia 28, 3-9 (1998) [Hungarian]

33. Jakubovits E, Janecskó M, Varga K, Diószeghy Cs, Pénzes I A mútét elótti pszichés felkészítés és a narkózis alatti pozitív szuggesztiók hatékonysága a perioperatív időszakban [The effectiveness of preoperative psychological preparatation and positive suggestions given during anesthesia in the perioperative period] Aneszteziológia és Intenzív Terápia 35, 3-12 (2005) [Hungarian]

34. Block RI, Ghoneim MM, Sum Ping ST, Ali MA: Efficacy of therapeutic suggestions for improved postoperative recovery presented during general anesthesia. Anesthesiology 75, 746-755 (1991)

35. Dawson PR, Van Hamel C, Wilkinson D, Warwick P, O'Connor $\mathrm{M}$ : Patient-controlled analgesia and intra-operative suggestion. Anaesthesia 56, 65-69 (2001)

36. Melzack R, Germain M, Belanger E, Fuchs PN, Swick R: Positive intrasurgical suggestion fails to affect postsurgical pain. J Pain Symptom Manage 11, 103-107 (1996)

37. Blankfield RP, Zyzanski SJ, Flocke SA, Alemagno S, Scheurman $\mathrm{K}$ : Taped therapeutic suggestions and taped music as adjuncts in the care of coronary-artery-bypass patients. Am J Clin Hypn 37, 32-42 (1995)
38. Van der Laan WH, van Leeuwen BL, Sebel PS: Therapeutic suggestion has no effect on postoperative morphine requirements. Anesth Analg 82, 148-152 (1996)

39. Boeke S, Bonke B, Bouwhuis-Hoogerwerf ML, Bovill JG, Zwaveling A: Effects of sounds presented during general anaesthesia on postoperative course. Br J Anaesth 60, 697-702 (1988)

40. Nilsson U, Rawal N, Enqvist B, Unosson M: Analgesia following music and therapeutic suggestions in the PACU in ambulatory surgery; A randomized controlled trial. Acta Anaesthesiol Scand 47, 278-283 (2003)

41. Liu WHC, Standen PJ, Aitkenhead, AR: Therapeutic suggestions during general anaesthesia in patients undergoing hysterectomy. Br J Anaesth 68, 277-281 (1992)

42. Varga K, Diószeghy C, Fritúz G: Suggestive communication with the ventilated patient. Eur J Mental Health 2, 137-147 (2007)

43. Szilágyi AK, Diószeghy C, Benczúr L, Varga K: Effectiveness of psychological support based on positive suggestion with the ventilated patient. Eur J Mental Health 2, 149-170 (2007)

44. Edelson J, Fitzpatrick JL: A comparison of cognitive-behavioral and hypnotic treatments of chronic pain. J Clin Psychol 45, 316$323(1989)$

45. Derbyshire SW, Whalley MG, Oakley DA: Fibromyalgia pain and its modulation by hypnotic and non-hypnotic suggestion: An fMRI analysis. Eur J Pain 13, 542-550 (2009)

46. Castel A, Perez M, Sala J, Padrol A, Rull M: Effect of hypnotic suggestion on fibromyalgic pain: Comparison between hypnosis and relaxation. Eur J Pain 11, 463-468 (2007)

47. Thomas KB: General practice consultations: Is there any point in being positive? Br Med J (Clin Res Ed) 294, 1200-1202 (1987)

48. Spanos NP, Stenstrom RJ, Johnston JC: Hypnosis, placebo, and suggestion in the treatment of warts. Psychosom Med 50, 245260 (1988)

49. Varga K, Diószeghy C (2004): A szuggesztiók jelentősége az orvos-beteg kommunikációban [The significance of suggestions in the doctor-patient communication]. In: Orvosi kommunikáció, ed Pilling J, Medicina Kiadó, Budapest, pp. 148-163 [Hungarian]

50. Varga K, Diószeghy C (2004): Az orvos üzenetei: szuggesztiók az orvosi gyakorlatban [Doctors' messages: Suggestions in medical practice]. In: Rezidensképzés, ed Pilling J, Semmelweis Kiadó, Budapest, pp. 175-195 [Hungarian]

51. Varga K (szerk.) (2005): Szuggesztív kommunikáció [Suggestive communication]. Országos Addiktológiai Intézet, Budapest [Hungarian]

52. Varga K, Diószeghy C (2001): Hútésbefizetés avagy a szuggesztiók szerepe a mindennapi orvosi gyakorlatban [Cash in for refrigeration, or the role of suggestions in everyday medical practice]. Pólya Kiadó, Budapest [Hungarian]

53. Cruise CJ, Chung F, Yogendran S, Little D: Music increases satisfaction in elderly outpatients undergoing cataract surgery. Can J Anaesth 44, 43-48 (1997) 